\title{
Reductive dissolution of pyrite by methanogenic archaea
}

\author{
Devon Payne $\mathbb{D}^{1} \cdot$ Rachel L. Spietz $\mathbb{B}^{1} \cdot$ Eric S. Boyd $\mathbb{1}^{1}$
}

Received: 10 March 2021 / Revised: 10 May 2021 / Accepted: 27 May 2021 / Published online: 10 June 2021

(c) The Author(s) 2021. This article is published with open access

\begin{abstract}
The formation and fate of pyrite $\left(\mathrm{FeS}_{2}\right)$ modulates global iron, sulfur, carbon, and oxygen biogeochemical cycles and has done so since early in Earth's geological history. A longstanding paradigm is that $\mathrm{FeS}_{2}$ is stable at low temperature and is unavailable to microorganisms in the absence of oxygen and oxidative weathering. Here, we show that methanogens can catalyze the reductive dissolution of $\mathrm{FeS}_{2}$ at low temperature $\left(\leq 38^{\circ} \mathrm{C}\right)$ and utilize dissolution products to meet cellular iron and sulfur demands associated with the biosynthesis of simple and complex co-factors. Direct access to $\mathrm{FeS}_{2}$ is required to catalyze its reduction and/or to assimilate iron monosulfide that likely forms through coupled reductive dissolution and precipitation, consistent with close associations observed between cells and $\mathrm{FeS}_{2}$. These findings demonstrate that $\mathrm{FeS}_{2}$ is bioavailable to anaerobic methanogens and can be mobilized in low temperature anoxic environments. Given that methanogens evolved at least 3.46 Gya, these data indicate that the microbial contribution to the iron and sulfur cycles in ancient and contemporary anoxic environments may be more complex and robust than previously recognized, with impacts on the sources and sinks of iron and sulfur and other bio-essential and thiophilic elements such as nickel and cobalt.
\end{abstract}

\section{Introduction}

Pyrite $\left(\mathrm{FeS}_{2}\right)$ is the most abundant sulfide mineral in Earth's crust and its formation and fate are key controls on the biogeochemical cycles of iron (Fe), sulfur (S), carbon, and oxygen $\left(\mathrm{O}_{2}\right)$ [1]. However, the specific role of sulfide minerals, such as $\mathrm{FeS}_{2}$, in these cycles has changed drastically over geological time [2, 3]. Isotopic evidence suggests that $\mathrm{FeS}_{2}$ has formed in sedimentary or volcanic environments since at least $3.81 \mathrm{Gya}$ [4]. Yet, prior to the advent of oxygenic photosynthesis and the gradual accumulation of $\mathrm{O}_{2} \sim 2.4$ Gya (as reviewed in $[5,6]$ ), biotic and abiotic oxidative weathering of $\mathrm{FeS}_{2}$ with $\mathrm{O}_{2}$, the primary driver of sulfate $\left(\mathrm{SO}_{4}{ }^{2-}\right)$ input into oceans [7], was of minimal importance $[3,6,8,9]$. Furthermore, reduction of $\mathrm{FeS}_{2}$ has only been demonstrated at high temperature $\left(>90^{\circ} \mathrm{C}\right)$ in abiotic laboratory reactors containing artificially high

Supplementary information The online version contains supplementary material available at https://doi.org/10.1038/s41396021-01028-3.

Eric S. Boyd

eric.boyd@montana.edu

1 Department of Microbiology and Immunology, Montana State University, Bozeman, MT, USA
( $>15$ bar) concentrations of hydrogen $\left(\mathrm{H}_{2}\right)$ [10, 11]. Together, these data imply that once iron sulfide minerals such as $\mathrm{FeS}_{2}$ form in low temperature sulfidic and anoxic environments, they remain largely unavailable to biology since they cannot be extensively mobilized through oxidative or reductive weathering [3]. This raises key questions as to how anaerobic microorganisms acquire $\mathrm{Fe}$ (and other thiophilic metals such as nickel and cobalt) and $S$ to meet biosynthetic demands in contemporary and past anoxic environments that favor formation of iron sulfide minerals, such as sulfidic freshwater or marine sediments [1, 12-14].

All cells require $\mathrm{Fe}$ and $\mathrm{S}$, which are key components of amino acids, vitamins, and a variety of co-enzymes and cofactors. This includes both simple and complex biological iron-sulfur ([Fe-S]) clusters that function in electron transfer, catalysis, substrate binding and activation, and other purposes $[15,16]$. As a consequence of their functional versatility, $[\mathrm{Fe}-\mathrm{S}]$ clusters are ubiquitous in all life forms $[15,17]$ and have central roles in photosynthesis, respiration, and fermentation [18].

Methanogenic archaea are argued to be the most primitive of extant organisms [19, 20], and isotopic evidence preserved in the rock record indicates their presence as early as $\sim 3.46$ Gya [21]. Despite their early emergence during the anoxic Archean, when free Fe and/or S may have been limited due to precipitation as sulfide minerals $[2,3]$, methanogens have been shown to utilize [Fe-S] 
clusters more extensively than other organisms. Specifically, Methanococcus maripaludis cells were shown to contain $\sim 15$ fold more $[\mathrm{Fe}-\mathrm{S}]$ clusters per mg protein than Escherichia coli cells [22] and methanogen genomes code for a higher number of putative [Fe-S] cluster binding proteins than those of facultative anaerobes and obligate aerobes [23].

The types of S sources that support methanogens vary based on their evolutionary history. Methanogens that belong to more primitive (Class I) lineages (Methanopyrales, Methanobacteriales, and Methanococcales) tend to be grown with sulfide $\left(\mathrm{HS}^{-} / \mathrm{H}_{2} \mathrm{~S}\right)$ as their $\mathrm{S}$ source whereas more recently evolved (Class II) lineages (Methanocellales, Methanomicrobiales, and Methanosarcinales) can also be grown with cysteine as their sulfur source [22, 24]. Sulfide is toxic to methanogens [25], but toxicity can be alleviated by precipitation with metals, such as ferrous iron ( $\mathrm{Fe}(\mathrm{II})$ ), nickel (II), or cobalt (II) [26]. Sulfide readily reacts with $\mathrm{Fe}(\mathrm{II})$, resulting in the formation of transient aqueous iron monosulfide clusters $\left(\mathrm{FeS}_{(\mathrm{aq})}\right)$ via Eq. (1) [27] that can condense to form metastable and less soluble nanoparticulate iron sulfide mineral phases such as mackinawite $\left(\mathrm{FeS}_{(\text {mack) }}\right)$ via Eq. (2) [27-29]. Depending on the type and abundance of aqueous $\mathrm{S}$ species in an environment (e.g., $\mathrm{H}_{2} \mathrm{~S}$ or polysulfide $\left(\mathrm{S}_{\mathrm{x}}{ }^{2-}\right)$ ), dissolution and/or solid-state transformation of $\mathrm{FeS}_{\text {(mack) }}$ can occur and can result in the formation of $\mathrm{FeS}_{2}$ via Eqs. (3) and (4) [13, 27, 29]:

$$
\begin{aligned}
\mathrm{H}_{2} \mathrm{~S}_{(\mathrm{aq})}+\mathrm{Fe}(\mathrm{II})_{(\mathrm{aq})} & \rightarrow \mathrm{FeS}_{(\mathrm{aq})}+2 \mathrm{H}^{+} \\
\mathrm{FeS}_{(\mathrm{aq})} & \rightarrow \mathrm{FeS}_{(\text {mack })} \\
\mathrm{FeS}_{(\text {mack })}+\mathrm{H}_{2} \mathrm{~S}_{(\mathrm{aq})} & \rightarrow \mathrm{FeS}_{2}+\mathrm{H}_{2(\mathrm{~g})} \\
\mathrm{FeS}_{(\text {mack })}+\mathrm{S}_{\mathrm{X}}^{2-}(\mathrm{aq}) & \rightarrow \mathrm{FeS}_{2}+\mathrm{S}_{\mathrm{x}-1}^{2-}(\mathrm{aq})
\end{aligned}
$$

The anoxic, sulfidic environments that anaerobic methanogens inhabit can have high concentrations of Fe(II), which would tend to favor the formation of iron sulfide minerals including $\mathrm{FeS}_{\text {(mack) }}$ and $\mathrm{FeS}_{2}[27,29]$. However, $\mathrm{FeS}_{2}$ is reportedly stable under anoxic, low temperature conditions $[10,11]$ and, to date, has not been shown to be bioavailable to microorganisms in the absence of oxygen or alternative oxidants (e.g., manganese oxides, ferric iron ions) that themselves require $\mathrm{O}_{2}$ to generate [30].

Here, we characterized the growth and methanogenesis activity of the model Class I and II methanogens, Methanococcus voltae strain $\mathrm{A} 3$ and Methanosarcina barkeri strain MS, respectively, in defined medium (Supplementary Online Materials (SOM) Tables S1 and S2). M. voltae A3 was originally isolated from a saltmarsh [24], whereas M. barkeri MS was originally isolated from an anaerobic sewage digestor [31]. M. voltae and M. barkeri were provided with canonical $\mathrm{Fe}$ and $\mathrm{S}$ sources $\left(\mathrm{Fe}\left(\mathrm{NH}_{4}\right)_{2}\left(\mathrm{SO}_{4}\right)_{2}\right.$ • $6 \mathrm{H}_{2} \mathrm{O}$ and $\mathrm{Na}_{2} \mathrm{~S} \cdot 9 \mathrm{H}_{2} \mathrm{O}$ or L-cysteine $\mathrm{HCl}$, respectively), laboratory synthesized nanoparticulate $\mathrm{FeS}_{2}$ or $\mathrm{FeS}_{\text {(mack), or }}$ powdered specimen $\mathrm{FeS}_{2}(63-125 \mu \mathrm{m}$ diameter) as their sole $\mathrm{Fe}$ and $\mathrm{S}$ sources. All minerals used in our experiments were subjected to multiple washing steps to remove trace $\mathrm{Fe}$ and $\mathrm{S}$ sources that may have formed during synthesis or mineral crushing. X-ray diffraction spectra of minerals used in growth experiments confirm that they correspond to previously characterized $\mathrm{FeS}_{2}$ or $\mathrm{FeS}_{\text {(mack) }}$ standards (SOM Fig. S1). The size distribution of laboratory synthesized $\mathrm{FeS}_{2}$, determined via field emission scanning electron microscopy (FE-SEM), ranged from 0.22 to $4.49 \mu \mathrm{m}$ with small framboids commonly aggregated into larger particles (SOM Fig. S2). Growth was monitored via direct cell counts (M. voltae) or DNA yield due to cell aggregation (M. barkeri), and methanogenesis activity was monitored by methane $\left(\mathrm{CH}_{4}\right)$ production via gas chromatography.

\section{Materials and methods}

\section{Preparation of synthetic pyrite}

All chemicals used in mineral synthesis were American Chemical Society grade or higher. All glassware was first washed in $10 \%$ nitric acid and rinsed three times with $18.2 \Omega$ MilliQ $\mathrm{H}_{2} \mathrm{O}\left(\mathrm{MQ} \mathrm{H}_{2} \mathrm{O}\right)$. Pyrite $\left(\mathrm{FeS}_{2}\right)$ was synthesized in the lab according to Berner [32]. Briefly, within an anaerobic chamber (Coy Labs, Grass Lake, MI), $14.4 \mathrm{~g}$ $\mathrm{Na}_{2} \mathrm{~S} \cdot 9 \mathrm{H}_{2} \mathrm{O}$ and $16.7 \mathrm{~g} \mathrm{FeSO}_{4} \cdot 7 \mathrm{H}_{2} \mathrm{O}$ were separately dissolved in $50 \mathrm{ml}$ of anoxic MQ $\mathrm{H}_{2} \mathrm{O}$. These two solutions were then combined into a $500 \mathrm{ml}$ bottle and stirred vigorously for $15 \mathrm{~min}$, at which point $2.1 \mathrm{~g}$ of elemental sulfur was added. The bottle was then sealed with a butyl rubber stopper, removed from the chamber, and bubbled with $\mathrm{N}_{2}$ passed over heated $\left(200^{\circ} \mathrm{C}\right)$ and $\mathrm{H}_{2}$-reduced copper shavings for $45 \mathrm{~min}$. Following purging, the solution was incubated anoxically for 4 days at $65^{\circ} \mathrm{C}$ and then for another 4 days at $85^{\circ} \mathrm{C}$. After incubation, the $\mathrm{FeS}_{2}$ was washed (via centrifugation and decanting) in the following series to remove unreacted $\mathrm{HS}^{-}, \mathrm{Fe}(\mathrm{II}), \mathrm{FeS}$, and $\mathrm{S}^{0}$ : four rinses with $1 \mathrm{~N} \mathrm{HCl}$, one rinse with boiling $6 \mathrm{~N} \mathrm{HCl}$, two rinses with $\mathrm{MQ} \mathrm{H}_{2} \mathrm{O}$, three rinses with $>99.5 \%$ acetone, and, finally, three rinses with $0.2 \mu \mathrm{m}$ filter-sterilized MQ $\mathrm{H}_{2} \mathrm{O}$. After washing, the $\mathrm{FeS}_{2}$ was pelleted via centrifugation, brought into an anaerobic chamber, the aqueous phase decanted, and the pellet resuspended in sterile, anoxic MQ $\mathrm{H}_{2} \mathrm{O}$ in a sterile serum bottle and was stoppered. Finally, the headspace of the bottle was purged with $0.2 \mu \mathrm{m}$ filtered $\mathrm{N}_{2}$ gas. The $\% \mathrm{w} / \mathrm{v}$ of the slurry was determined by drying $1 \mathrm{ml}$ of slurry in triplicate under $\mathrm{N}_{2}$ in pre-weighed glass serum bottles. 
Mackinawite $\left(\mathrm{FeS}_{(\text {mack })}\right)$ was synthesized similarly to $\mathrm{FeS}_{2}$. Within an anaerobic chamber $1.14 \mathrm{~g} \mathrm{Na}_{2} \mathrm{~S} \bullet 9 \mathrm{H}_{2} \mathrm{O}$ and $1.67 \mathrm{~g} \mathrm{FeSO}_{4} \cdot 7 \mathrm{H}_{2} \mathrm{O}$ were separately dissolved in $10 \mathrm{ml}$ of anoxic MQ $\mathrm{H}_{2} \mathrm{O}$. The solutions were then combined and vigorously stirred in a $50 \mathrm{ml}$ glass flask for $15 \mathrm{~min}$. The $\mathrm{FeS}_{\text {(mack) }}$ solution was washed three times with anoxic MQ $\mathrm{H}_{2} \mathrm{O}$, as described above. Inside an anaerobic chamber, the final mineral pellet was resuspended in $15 \mathrm{ml}$ of $0.2 \mu \mathrm{m}$ filter-sterilized, anoxic $\mathrm{MQ} \mathrm{H}_{2} \mathrm{O}$ and then transferred to a sterile serum bottle and stoppered. Finally, the headspace of the bottle was purged with $0.2 \mu \mathrm{m}$ filtered $\mathrm{N}_{2}$ gas. The $\%$ $\mathrm{w} / \mathrm{v}$ of the slurry was determined as described above.

Specimen $\mathrm{FeS}_{2}$, obtained from Zacatecas, Mexico (Ward's Science, Rochester, NY), was crushed with an ethanol sterilized jaw crusher (Gilson, Lewis Center, $\mathrm{OH}$ ) in a laminar flow hood. Crushed mineral was applied to a sterile sieve stack (U.S. Standard \#10/2000 $\mu$ m, U.S. Standard \#35/500

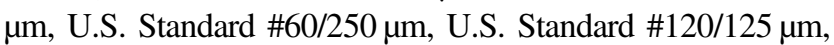
U.S. Standard \#230/63 $\mu \mathrm{m}$, and catch pan; all $8^{\prime \prime}$ diameter) in a laminar flow hood. The sieve stack was mechanically shaken ( 275 oscillations and $\sim 150$ taps per minute) for 10 min using a Ro-Tap ${ }^{\oplus}$ RX-29 mechanical sieve shaker (W.S. Tyler, Mentor, $\mathrm{OH})$. Following sieving, the sieve stack was returned to the laminar flow hood and the $63-125 \mu \mathrm{m}$ fraction was collected, washed as described above for laboratory synthesized $\mathrm{FeS}_{2}$, and dried at room under $\mathrm{N}_{2}$ in a sterile serum bottle sealed with a butyl rubber stopper.

Minerals were characterized using a SCINTAG X-1 system X-ray powder diffraction (XRD) spectrometer (XRD Eigenmann GmbH, Mannheim, Germany), a JEOL JSM6100 scanning electron microscope equipped with an energy dispersive X-ray spectrometer (JEOL USA INC., Peabody, MA), and a Zeiss SUPRA 55VP FE-SEM (Zeiss, Oberkochen, Germany). Samples for mineral characterization were prepared by drying $\sim 10 \mathrm{ml}$ of the mineral slurry or reacted mineral in a sealed serum bottle under a stream of $\mathrm{N}_{2}$.

\section{Strains and cultivation media}

Methanococcus voltae strain A3 was obtained from the American Type Culture Collection (ATTC-BAA-1334). $M$. voltae was grown in $\mathrm{Fe}$ - and $\mathrm{S}$-free basal medium that contained $\left(\mathrm{g} \mathrm{l}^{-1}\right)$ : NaCl, 21.98; $\mathrm{MgCl}_{2} \cdot 6 \mathrm{H}_{2} \mathrm{O}, 5.10$; $\mathrm{NaHCO}_{3}, 5.00 ; \mathrm{NH}_{4} \mathrm{Cl}, 0.50 ; \mathrm{K}_{2} \mathrm{HPO}_{4}, 0.14 ; \mathrm{KCl}, 0.33$; $\mathrm{CaCl}_{2} \cdot 2 \mathrm{H}_{2} \mathrm{O}, 0.10$ (SOM Table S2). The basal medium was amended with $0.01 \mathrm{~g} \mathrm{l}^{-1} \mathrm{Fe}\left(\mathrm{NH}_{4}\right)_{2}\left(\mathrm{SO}_{4}\right)_{2} \cdot 6 \mathrm{H}_{2} \mathrm{O}$ and $0.48 \mathrm{~g}^{-1} \mathrm{Na}_{2} \mathrm{~S} \bullet 9 \mathrm{H}_{2} \mathrm{O}$ for $\mathrm{Fe}(\mathrm{II}) / \mathrm{HS}^{-}$grown cells. Sulfide was added from an anoxic, sterile stock solution $30 \mathrm{~min}$ prior to inoculation. Basal medium was amended (each $1 \%$ $\mathrm{v} / \mathrm{v}$ ) with trace element, vitamin, and organic solutions. The trace element solution used was based on Whitman et al. [33] and was amended to omit Fe and replace sulfate salts with chloride salts at the same molar concentrations. The trace element solution contained $\left(\mathrm{g} \mathrm{l}^{-1}\right)$ : nitriloacetic acid, 1.500; $\mathrm{MnCl}_{2} \bullet 4 \mathrm{H}_{2} \mathrm{O}, 0.085 ; \mathrm{CoCl}_{2} \bullet \mathrm{H}_{2} \mathrm{O}, 0.100 ; \mathrm{ZnCl}_{2}$, 0.047; $\mathrm{CuCl}_{2} \cdot 2 \mathrm{H}_{2} \mathrm{O}, 0.0683 ; \mathrm{NiCl}_{2} \cdot 6 \mathrm{H}_{2} \mathrm{O}, 0.0683$; $\mathrm{Na}_{2} \mathrm{SeO}_{3}, 0.200 ; \mathrm{Na}_{2} \mathrm{MoO}_{4} \cdot 2 \mathrm{H}_{2} \mathrm{O}, 0.100 ; \mathrm{Na}_{2} \mathrm{WO}_{4} \cdot$ $2 \mathrm{H}_{2} \mathrm{O}, 0.100$. The vitamin solution contained $\left(\mathrm{g} \mathrm{l}^{-1}\right)$ : pyridodoxine $\mathrm{HCl}, 0.01$; thiamine $\mathrm{HCl}, 0.005$; riboflavin, $0.005 \mathrm{~g}$; nicotinic acid, 0.005 ; calcium $\mathrm{D}(+)$ pantothenate, 0.005; biotin, 0.002; folic acid, 0.002; cobalamin, 0.0001 . The organics solution consisted of $1 \mathrm{M}$ sodium acetate • $3 \mathrm{H}_{2} \mathrm{O}, 75 \mathrm{mM}$ L-leucine $\mathrm{HCl}$, and $75 \mathrm{mM}$ L-isoleucine $\mathrm{HCl}$. Cultures of $M$. voltae grown with $\mathrm{N}_{2}-\mathrm{CO}_{2}$ were supplemented with a $40 \%(\mathrm{wt} / \mathrm{v})$ sodium formate stock solution added to a final concentration of $0.4 \%(\mathrm{v} / \mathrm{v})$ prior to inoculation.

Methanosarcina barkeri strain MS was purchased from the ATCC (BAA-2329) and grown on Fe- and S-free basal medium that contained $\left(\mathrm{g} \mathrm{L}^{-1}\right)$ : $\mathrm{NaCl}, 1.0 ; \mathrm{MgCl}_{2} \cdot 6 \mathrm{H}_{2} \mathrm{O}$, 0.4, $\mathrm{NaHCO}_{3}, 2.00 ; \mathrm{NH}_{4} \mathrm{Cl}, 0.54 ; \mathrm{KCl}, 0.5 ; \mathrm{K}_{2} \mathrm{HPO}_{4}, 0.35$; $\mathrm{KH}_{2} \mathrm{PO}_{4}, 0.23 ; \mathrm{CaCl}_{2} \cdot 2 \mathrm{H}_{2} \mathrm{O}, 0.10$ (SOM Table S3). The basal medium was amended with $0.01 \mathrm{~g} \mathrm{l}^{-1} \mathrm{Fe}\left(\mathrm{NH}_{4}\right)_{2}\left(\mathrm{SO}_{4}\right)_{2} \bullet$ $6 \mathrm{H}_{2} \mathrm{O}$ and $0.35 \mathrm{~g} \mathrm{l}^{-1} \mathrm{~L}$-cysteine $\mathrm{HCl}$ for $\mathrm{Fe}(\mathrm{II}) /$ cysteine grown cells. Sterile, anoxic stock trace metals and vitamins solutions were prepared and added to the basal medium (1\% v/v final concentration) prior to inoculation. The iron-free SL-10 trace metals solution contained $\left(\mathrm{gl}^{-1}\right)$ : $\mathrm{ZnCl}_{2}, 0.070 ; \mathrm{MnCl}_{2} \cdot$ $4 \mathrm{H}_{2} \mathrm{O}, 0.100 ; \mathrm{H}_{3} \mathrm{BO}_{3}, 0.006 ; \mathrm{CoCl}_{2} \bullet 6 \mathrm{H}_{2} \mathrm{O}, 0.190 ; \mathrm{CuCl}_{2}$ • $2 \mathrm{H}_{2} \mathrm{O}, 0.002 ; \mathrm{NiCl}_{2} \bullet 6 \mathrm{H}_{2} \mathrm{O}, 0.024 ; \mathrm{Na}_{2} \mathrm{MoO}_{4} \bullet 2 \mathrm{H}_{2} \mathrm{O}, 0.036$. The vitamin solution used was as described for $M$. voltae above. Sterile, anoxic stock solutions of methanol and acetate were added to final concentrations of $0.5 \%$ (v/v) and $40 \mathrm{mM}$, respectively.

All medium components, with the exception of $\mathrm{NaHCO}_{3}$, were dissolved in $\mathrm{MQ} \mathrm{H}_{2} \mathrm{O}$ and then boiled for $15 \mathrm{~min}$. After boiling, the bottle containing the medium was sealed with a butyl rubber stopper and sparged with $\mathrm{N}_{2}$ passed over a heated copper column for $1 \mathrm{~h} \mathrm{~L}^{-1}$ of medium. After degassing, the medium was sealed, brought into an anaerobic chamber, and $\mathrm{NaHCO}_{3}$ was added as specified above. After adding these components, the $\mathrm{pH}$ of the medium was adjusted to 7.00 using anoxic $2 \mathrm{M} \mathrm{HCl}$ or $1 \mathrm{M} \mathrm{NaOH}$. Seventy-five $\mathrm{ml}$ of media were dispensed into $165 \mathrm{ml}$ serum bottles (DWK Life Sciences, Milville, NJ) that had been acid-washed in $10 \%$ nitric acid and sealed with black rubber stoppers (Glasgerätebau Ochs GmbH, Bovenden, Germany) and aluminum crimp caps. The serum bottles were then brought out of the chamber and the headspace was purged with $\mathrm{N}_{2}$ for $30 \mathrm{~min}$. The bottles were then autoclaved for 20 $\min$ at $123^{\circ} \mathrm{C}$.

Synthesized $\mathrm{FeS}_{2}$ was added to microcosms from the prepared slurry at a final concentration of $2 \mathrm{mM}$ of $\mathrm{Fe}$, and specimen $\mathrm{FeS}_{2}$ powder was added to microcosms at $1.5 \mathrm{~g}$ per $75 \mathrm{ml}$ of medium $(167 \mathrm{mM})$. This amount was chosen to normalize for differences in the estimated surface area between laboratory synthesized $\mathrm{FeS}_{2}$ and powdered specimen 
$\mathrm{FeS}_{2}$. Surface area of laboratory synthesized $\mathrm{FeS}_{2}$ was estimated by calculating the average particle size of synthesized $\mathrm{FeS}_{2}$ framboids $(0.74 \mu \mathrm{m}$ diameter) then calculating surface area of the particles assuming framboids were octahedral. Briefly, ten fields of view were randomly collected using back-scattered secondary electron imaging on a Zeiss SUPRA 55VP FE-SEM. The images were imported into ImageJ software (Rasband, W.S., ImageJ, U.S. National Institutes of Health, Bethesda, Maryland, USA, https://imagej.nih.gov/ij/, 1997-2018.) and particle sizes were calculated using the "Analyze Particles" function. The surface area of specimen $\mathrm{FeS}_{2}$ was estimated assuming an average particle diameter of $94 \mu \mathrm{m}$, the midpoint of the $63-125 \mu \mathrm{m}$ size fraction, and octahedral form.

\section{Cultivation procedures}

Cultures of $M$. voltae and M. barkeri were maintained by weekly transfers (10\% v/v) into fresh medium with $\mathrm{Fe}$ (II) as Fe source, $\mathrm{HS}^{-}$or L-cysteine as $\mathrm{S}$ source, and formate or methanol as methanogenesis substrate, respectively. Cells were washed prior to inoculation by pelleting them in sealed $50 \mathrm{ml}$ centrifuge tubes (Globe Scientific, Mahwah, NJ) at $4700 \times g$ for $20 \mathrm{~min}$ at $4{ }^{\circ} \mathrm{C}$ in a swing-out bucket rotor. Spent medium was decanted in an anaerobic chamber and the cell pellet was resuspended in sterile and anoxic $\mathrm{Fe} / \mathrm{S}$ free basal medium. All experiments used washed M. voltae and $M$. barkeri cells grown with $26 \mu \mathrm{M} \mathrm{Fe}(\mathrm{II})$ and either 2 $\mathrm{mM} \mathrm{HS}^{-}$or $2 \mathrm{mM}$ L-cysteine as inoculum $(10 \% \mathrm{v} / \mathrm{v})$, respectively. After inoculation, the headspaces of microcosms were flushed with an 80:20 (v/v) mixture of $\mathrm{N}_{2}-\mathrm{CO}_{2}$ gas that had been passed through a $0.2 \mu \mathrm{m}$ filter for at least $15 \mathrm{~min}$ before being pressurized (final pressure of $3.14 \mathrm{~atm}$ ). M. voltae and M. barkeri were incubated at $38^{\circ} \mathrm{C}$. All cultures were incubated statically on their sides to minimize disruption of microbe-mineral interactions while maximizing gas diffusion.

\section{Measurement of activity and growth}

Headspace gas from microcosms was sampled with a $\mathrm{N}_{2}$ flushed syringe and stopcock and diluted with ultra-high purity $\mathrm{N}_{2}$ into CaliBond bags (Calibrated Instruments Inc., Manhasset, NY) prior to $\mathrm{CH}_{4}$ determination. $\mathrm{CH}_{4}$ was determined by gas chromatography by injecting $5 \mathrm{ml}$ of sample into an injector valve set at $55^{\circ} \mathrm{C}$ into an SRI $8610 \mathrm{C}$ gas chromatograph (SRI instruments, Torrance, CA) equipped with a $4.5 \mathrm{~m} \times 0.125^{\prime \prime}$ OD Hayesep DB $100 / 120$ packed column with the oven set to $44{ }^{\circ} \mathrm{C}$ (Valco Instrument Company Inc., Houston, TX). $\mathrm{CH}_{4}$ was detected by a flame-ionization detector set at $156{ }^{\circ} \mathrm{C}$ with $\mathrm{He}$ as carrier gas. $\mathrm{CH}_{4}$ peak area values were converted to ppm using a standard $\mathrm{CH}_{4}$ curve (EGAS Depot, Nampa, ID). Dissolved
$\mathrm{HS}^{-}$was determined via colorimetry $(670 \mathrm{~nm})$ using the methylene blue assay [34] and converted to total $\mathrm{HS}^{-}$ (dissolved and gas phase) using Henry's law. Absorbance was measured using a Genesys 10S Vis Spectrophotometer (Thermo Scientific, Waltham, MA).

Growth in cultures of $M$. voltae was determined by direct counting of cells using a Petroff-Hausser counting chamber on a Nikon YS100 light microscope with a $\times 100$ oil objective (Nikon, Tokyo, Japan). Prior to counting, cells were concentrated by centrifugation at $15,000 \times g$ for $15 \mathrm{~min}$ in a fixed-angle rotor. Despite efforts to minimize cell aggregation in cultures of M. barkeri, cells still aggregated necessitating an alternative approach to quantify growth. Quantification of DNA from M. barkeri was used as a proxy for cell growth. DNA was extracted using the FastDNA SPIN kit for soils (MP Biomedicals, Santa Ana, CA) with a modified protocol. First, $2 \mathrm{ml}$ of culture were pelleted via centrifugation at $20,000 \times g$ for $30 \mathrm{~min}$ at $20^{\circ} \mathrm{C}$. The supernatant was carefully decanted and $489 \mu \mathrm{l}$ of sodium phosphate buffer (MP Biomedicals, Santa Ana, CA) and $61 \mu \mathrm{l}$ of MT lysis buffer (MP Biomedicals) were used to resuspend the cell pellet. The resuspended pellet and buffer mixture were subjected to three rounds of freezing at $-80^{\circ} \mathrm{C}$ and thawing at $70^{\circ} \mathrm{C}$. The cell and lysis buffer mixture were transferred to a Lysis E tube (MP Biomedicals), homogenized on a bead beater for $40 \mathrm{~s}$ (Biospec Products, Bartlesville, OK), then centrifuged $14,000 \times g$ for $15 \mathrm{~min}$ at $4{ }^{\circ} \mathrm{C}$ to pellet cell debris. DNA in the supernatant was quantified using a Qubit HS dsDNA assay (Invitrogen, Carlsbad, CA).

\section{Dialysis membrane experiments}

Dialysis membranes of varying pore sizes were used to examine the requirement for direct cell contact with $\mathrm{FeS}_{2}$ or the size of extracellular proteins involved in catalyzing its reduction. A $12 \mathrm{~cm}$ length of Spectra/Por (Spectrum Labs Inc., Rancho Dominguez, CA) 3 dialysis tubing with either $3.5,25,50$, or $100 \mathrm{kDa}$ molecular weight cutoff was used for each bottle. The dialysis membranes were first washed by three cycles of soaking precut tubing in $\mathrm{MQ} \mathrm{H}_{2} \mathrm{O}$ for $30 \mathrm{~min}$ at $65^{\circ} \mathrm{C}$, followed by decanting and rinsing with fresh MQ $\mathrm{H}_{2} \mathrm{O}$. The tubing was then transferred to a bottle containing $50 \%$ ethanol, and the submerged membranes were then incubated overnight at $65^{\circ} \mathrm{C}$. The tubes were then handled in a UV-sterilized molecular hood with ethanol sterilized gloves and forceps where they were tied at one end with ethanol-soaked monofilament line (Berkley, Columbia, SC). To seal the bags in preparation for addition of $\mathrm{FeS}_{2}$, the end of the tubing was first folded over twice, then crimped with a dialysis clip (Spectrum Labs Inc., Rancho Dominguez, CA). The clip was then removed, leaving a fold that was amenable to tying with monofilament. The tubing was then returned to the $50 \%$ ethanol bottle, sparged with $\mathrm{N}_{2}$ gas for $1 \mathrm{~h}$, and 
brought into an anaerobic chamber. Monofilament line rather than dialysis clips was used to facilitate the entry of tubing into narrow mouthed $(20 \mathrm{~mm}$ diameter) serum bottles for cultivation experiments.

Inside the anaerobic chamber, the dialysis bags were rinsed in sterile and anoxic $\mathrm{MQ} \mathrm{H}_{2} \mathrm{O}$ to remove residual ethanol. Then, laboratory -synthesized $\mathrm{FeS}_{2}$ was added to dialysis bags as a slurry $(2 \mathrm{mM}$ final concentration Fe once in medium bottles), and the bags were resealed as described above with monofilament line. Finally, the outsides of all bags were rinsed with anoxic and sterile $\mathrm{MQ} \mathrm{H}_{2} \mathrm{O}$ and were transferred to pre-sterilized $165 \mathrm{ml}$ serum bottles containing $75 \mathrm{ml}$ of basal medium amended with vitamins, trace metals, and organics solution. The bottles were sealed with sterilized butyl rubber stoppers and purged with an 80:20 mixture of $0.2 \mu \mathrm{m}$ filtered $\mathrm{N}_{2}: \mathrm{CO}_{2}$ for $45 \mathrm{~min}$ to remove gas originating from the anaerobic chamber and were then pressurized (final pressure of $3.14 \mathrm{~atm}$ ). The bottles were then inoculated with washed, $\mathrm{Fe}(\mathrm{II}) / \mathrm{HS}^{-}$-grown cells $(10 \%$ $\mathrm{v} / \mathrm{v}$ inoculum). Positive controls contained $3.5 \mathrm{kDa}$ dialysis membranes and $\mathrm{FeS}_{2}$ that was not enclosed in the membrane. Unamended controls contained $3.5 \mathrm{kDa}$ dialysis membranes without any added Fe or $\mathrm{S}$ source.

\section{Electron microscopy}

Subsamples of cultures of $M$. voltae for use in FE-SEM imaging analyses were collected and incubated in $10 \mathrm{ml}$ of freshly prepared $2 \%$ glutaraldehyde solution in $0.1 \mathrm{M}$ phosphate buffer for $2 \mathrm{~h}$ at room temperature. Glutaraldehydefixed samples were applied to a Au-sputtered $0.2 \mu \mathrm{m}$ black Isopore polycarbonate filter (MilliporeSigma, Burlington, MA). The filter was subjected to an ethanol series $(25,50$, $70,85,95$, and $100 \%$ ) for complete dehydration, then stored dry at $4{ }^{\circ} \mathrm{C}$ until imaging in the Imaging and Chemical Analysis Laboratory at Montana State University. Images were taken using a high-resolution FE-SEM (Supra 55VP, Zeiss, Thornwood, NY) with a primary electron beam energy of $1 \mathrm{keV}$ at different magnifications. Samples were mounted on the FE-SEM holder using double-sided carbon tape and sputtered with a thin film of iridium for conductivity before loading to the FE-SEM chamber. Elemental mapping was acquired using energy dispersive X-ray spectroscopy with a Scanning Auger Electron Nanoprobe-Physical Electronics 710 and 10 and $20 \mathrm{kV}$ energy beam.

\section{Results and discussion}

\section{Reductive dissolution of $\mathrm{FeS}_{2}$ at low temperature}

Cultivation of $M$. voltae and $M$. barkeri, when provided with formate or methanol and acetate as the methanogenesis substrates, respectively, resulted in significant cell and $\mathrm{CH}_{4}$ production in cultures containing nanoparticulate $\mathrm{FeS}_{2}$ or canonical forms of $\mathrm{Fe}$ and $\mathrm{S}$ but were not observed in cultures unamended with Fe or S (Fig. 1a-d and Extended Data File 1). Growth of both $M$. voltae and M. barkeri was also observed with powdered specimen $\mathrm{FeS}_{2}$ as the sole $\mathrm{Fe}$ and S source (SOM Fig. S3). These observations indicate that both synthetic nanoparticulate $\mathrm{FeS}_{2}$ and specimen $\mathrm{FeS}_{2}$, the latter of which should be reflective of $\mathrm{FeS}_{2}$ commonly encountered by methanogens in natural environments, can serve as the sole $\mathrm{Fe}$ and $\mathrm{S}$ source for these cells.

Sulfide (referred to as $\mathrm{HS}^{-}$from here on) was detected in cultures of $M$. voltae and M. barkeri provided with nanoparticulate $\mathrm{FeS}_{2}$ but not in abiotic controls; concentrations of $\mathrm{HS}^{-}$increased with increased production of biomass and $\mathrm{CH}_{4}$ (Fig. 1e, $\mathrm{f}$ and Supplementary Data File 1). This is consistent with cells catalyzing the reductive dissolution of $\mathrm{FeS}_{2}$ to produce $\mathrm{HS}^{-}$. The accumulation of $\mathrm{HS}^{-}$suggests that the rate of $\mathrm{FeS}_{2}$ reduction by methanogens exceeds the rate of cellular $S$ uptake. To the extent that cells are not taking up $\mathrm{HS}^{-}$(discussed below), the amount of $\mathrm{HS}^{-}$that accumulated in the growth medium can be combined with the predicted cellular $S$ requirement per cell to provide a conservative estimate of the amount of $\mathrm{FeS}_{2}$ reduction in laboratory grown cultures. The estimated $\mathrm{S}$ content of $\log$ phase Methanococcus maripaludis, a close relative of $M$. voltae, is $349 \mathrm{nmol}$ per $\mathrm{mg}$ protein [22]. The amount of protein in log phase $M$. voltae is $8.88 \times 10^{-10} \mathrm{mg} \mathrm{cell}^{-1}$ (E. S. Boyd, unpublished data). As such, an individual $M$. voltae cell during log phase is estimated to contain 0.31 fmol S. When this is combined with the amount of $\mathrm{HS}^{-}$that accumulates during $\mathrm{FeS}_{2}$ reduction, as normalized to an individual cell $\left(0.15 \mathrm{fmol}^{\text {cell }}{ }^{-1}\right.$, see Extended Data File 1), it is conservatively estimated that $M$. voltae catalyzes the reduction of $0.23 \mathrm{fmol} \mathrm{FeS}_{2}$ cell $^{-1}$ during log phase growth.

Importantly, acid labile Fe(II) was not detected in spent medium via the ferrozine assay $(\sim 11 \mu \mathrm{M}$ lower detection limit) at any point during the growth of $M$. voltae or $M$. barkeri (data not shown). This could indicate that the cells maintain aqueous $\mathrm{Fe}(\mathrm{II})$ below the limits of detection of our assay or that the $\mathrm{Fe}$ (II) phase that forms via $\mathrm{FeS}_{2}$ reduction (reverse of Eqs. (2)-(4)) undergoes rapid precipitation on the mineral surface. A coupled reductive dissolution and precipitation reaction has been proposed for abiotic reduction of $\mathrm{FeS}_{2}$ at high temperature, with iron monosulfide as mackinawite or pyrrhotite forming as the predominant $\mathrm{Fe}$ (II) phase(s) on the surface of $\mathrm{FeS}_{2}$ [10]. Together, these data indicate that representatives of both Class I and II methanogens can catalyze the reduction of $\mathrm{FeS}_{2}$ at low temperatures $\left(\leq 38^{\circ} \mathrm{C}\right)$ and raise the question of the form(s) of Fe and $\mathrm{S}$ that is assimilated to meet biosynthetic demands.

One source of $\mathrm{Fe}$ and $\mathrm{S}$ that could potentially support growth of methanogens during the reductive dissolution of 

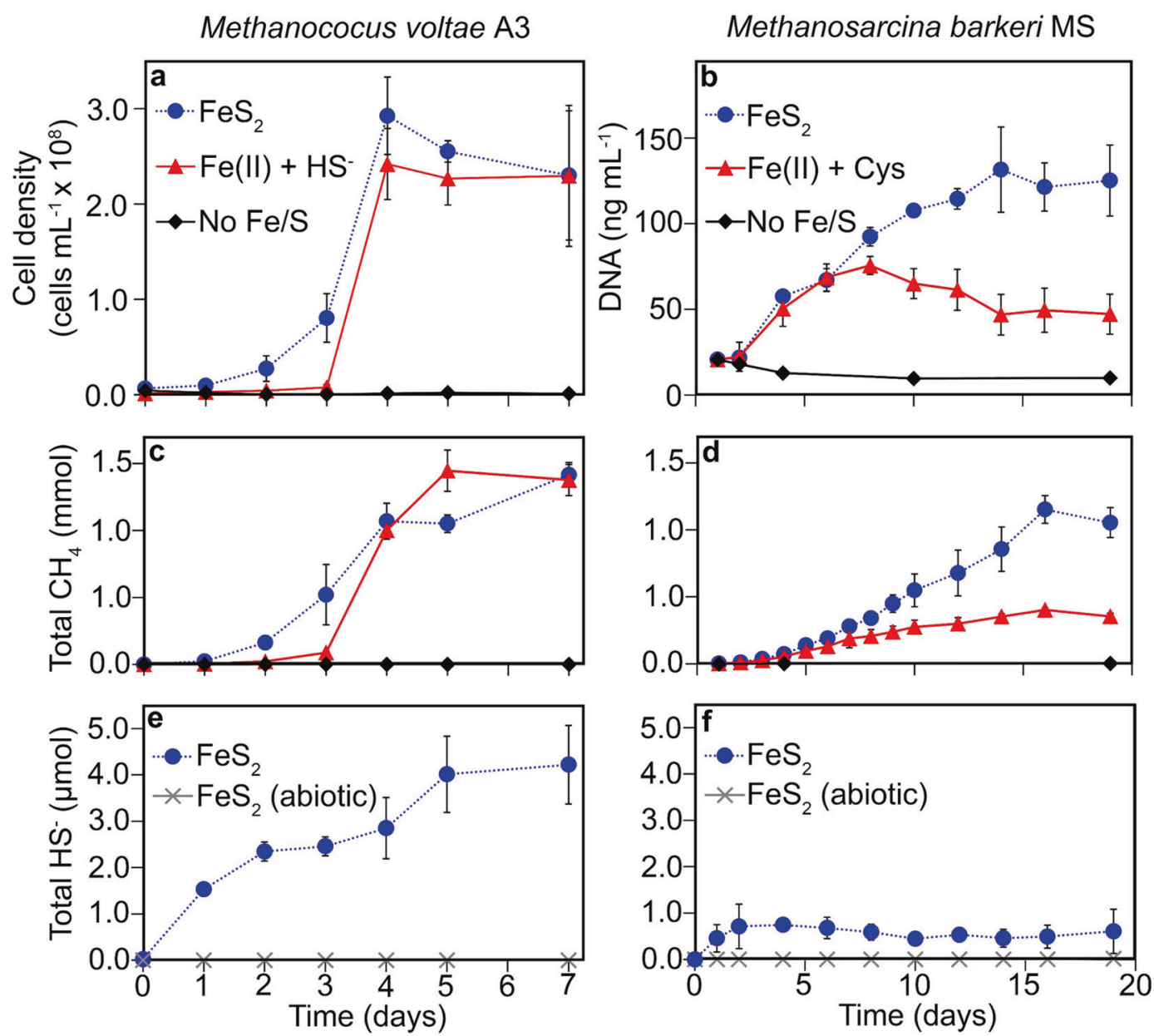

Fig. 1 Growth and activity of methanogens on different iron and sulfur sources. Production of biomass, methane, and sulfide in cultures of Methanococcus voltae provided with formate $(\mathbf{a}, \mathbf{c}, \mathbf{e}$, respectively) or Methanosarcina barkeri provided with methanol and acetate (c, d, f, respectively) as the methanogenesis substrate when grown with different iron and sulfur sources in defined medium. Legends in $\mathbf{a}$ and $\mathbf{c}$ and in $\mathbf{b}$ and $\mathbf{d}$ are the same. Ferrous iron and sulfide or cysteine were added to final concentrations of $26 \mu \mathrm{M}$ and

$\mathrm{FeS}_{2}$ is $\mathrm{FeS}_{\text {(mack) }}$, which would be expected to be produced if biological $\mathrm{FeS}_{2}$ reduction is taking place via the reverse reaction of Eqs. (3) or (4). Further, $\mathrm{FeS}_{\text {(mack) }}$ is a commonly detected form of iron monosulfide in low temperature settings [35] and is a possible precursor to the formation of $\mathrm{FeS}_{2}$ in these environments [29, 36]. Equilibrium dissolution of $\mathrm{FeS}_{\text {(mack) }}$ in non-acidic ( $\left.\mathrm{pH}>6.0\right)$ aqueous solutions results in the formation of $\mathrm{FeS}_{(\mathrm{aq})}$ as the dominant form of $\mathrm{Fe}(\mathrm{II})$ (reverse of Eq. (2)) when $\mathrm{HS}^{-}$is at a concentration exceeding $1 \mu \mathrm{M}$ [28]. Thus, to further evaluate the potential form of $\mathrm{Fe}$ and $\mathrm{S}$ supporting growth of cells, $M$. voltae was provided with nanoparticulate, laboratory -synthesized $\mathrm{FeS}_{2}$ or $\mathrm{FeS}_{\text {(mack) }}$ in the presence or absence of $1 \mathrm{mM}$ added $\mathrm{HS}^{-}$. This concentration of $\mathrm{HS}^{-}$was chosen such that any aqueous $\mathrm{Fe}$ (II) either dissociated from $\mathrm{FeS}_{\text {(mack) }}$ or from a trace laboratory contaminant, if present, would predominantly be
$2 \mathrm{mM}$, respectively. Laboratory synthesized pyrite was added to a final concentration of $2 \mathrm{mM} \mathrm{Fe}$. $\mathrm{CH}_{4}$, total methane; $\mathrm{HS}^{-}$, total sulfide; $\mathrm{Fe}(\mathrm{II})$, ferrous iron; Cys, cysteine; $\mathrm{FeS}_{2}$, pyrite. Data shown are the mean values for each condition with error bars reflecting the standard deviation of three replicate biological reactors; a single reactor for abiotic controls was monitored and thus error bars are not presented. Total $\mathrm{HS}^{-}$was monitored only in the $\mathrm{FeS}_{2}$ growth conditions. See Extended Data File 1 for $\mathrm{CH}_{4}$ and $\mathrm{HS}^{-}$data.

in the form of $\mathrm{FeS}_{(\mathrm{aq})}[28,29]$. M. voltae cultures showed no apparent difference in growth or activity with $\mathrm{FeS}_{\text {(mack) }}$ in the presence or absence of added $\mathrm{HS}^{-}$and these did not differ from the $\mathrm{Fe}(\mathrm{II}) / \mathrm{HS}^{-}$positive control (Fig. 2). M. barkeri also demonstrated growth on $\mathrm{FeS}_{(\text {mack }}$ as the sole Fe and S source (SOM Fig. S4). We also tested the growth of M. voltae on $\mathrm{FeS}_{2}$ in the presence or absence of $1 \mathrm{mM} \mathrm{HS}^{-}$and observed growth and surprisingly also observed $\mathrm{HS}^{-}$production from $\mathrm{FeS}_{2}$ even in the presence of added HS $^{-}$(SOM Fig. S5). Sulfide concentrations could not be accurately monitored in growth experiments with $\mathrm{FeS}_{\text {(mack) }}$ given that this mineral is partially soluble, acid labile, and forms nanoparticles ( 2 $\mathrm{nm}$ in size) [29] that cannot be readily size fractionated; these features interfere with the sulfuric acid-based methylene blue assay that was used to quantify $\mathrm{HS}^{-}$. Collectively, these results suggest 

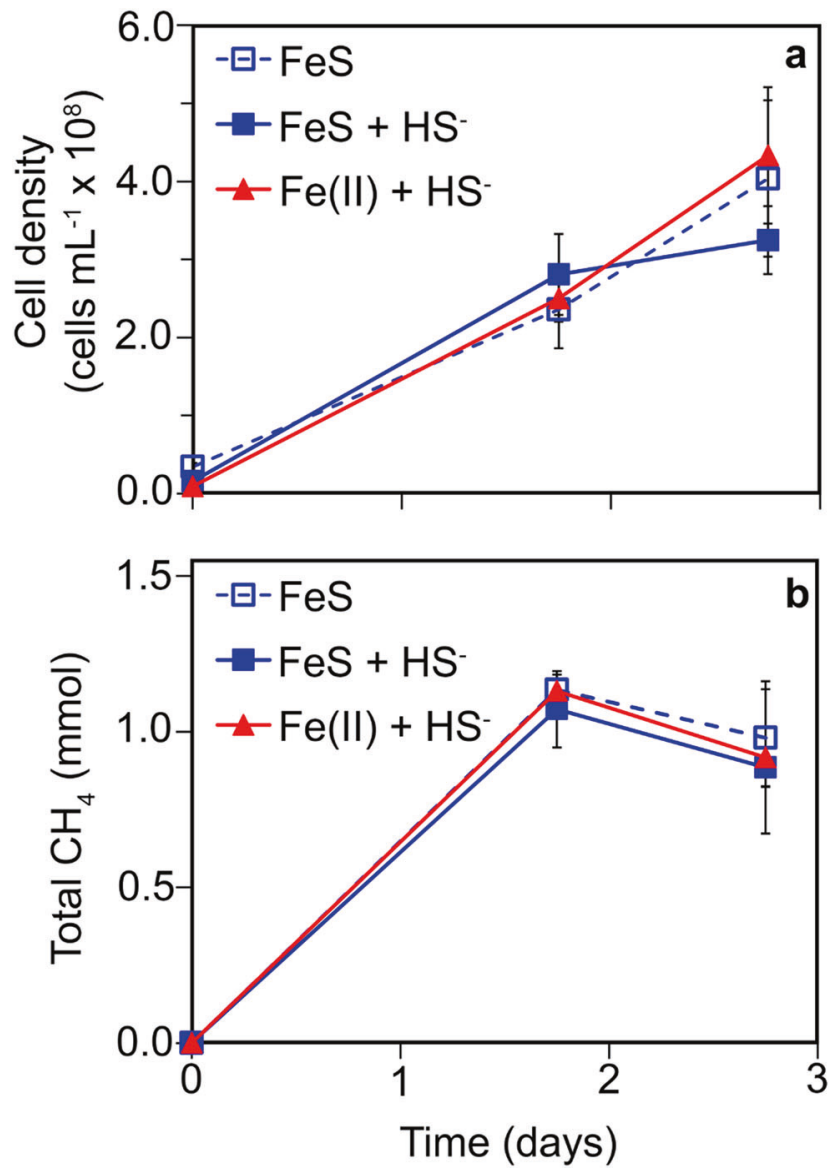

Fig. 2 Growth and activity of Methanococcus voltae provided with mackinawite as the sole iron and sulfur source. Production of cells (a) and methane (b) for M. voltae cultures. Cells were grown with synthetic mackinawite $(\mathrm{FeS})$ added to a final concentration of $2 \mathrm{mM}$ Fe with or without added $1 \mathrm{mM}$ added $\mathrm{HS}^{-}$. Cells provided with $\mathrm{Fe}$ (II) and $\mathrm{HS}^{-}$ served as the positive control. $\mathrm{CH}_{4}$, methane; $\mathrm{Fe}(\mathrm{II})$, ferrous iron; $\mathrm{HS}^{-}$, sulfide; FeS, mackinawite. Data shown are the mean values for each condition with error bars reflecting the standard deviation of three replicate biological reactors. See Extended Data File 1 for $\mathrm{CH}_{4}$ and $\mathrm{HS}^{-}$data.

that cells can use mineral forms of $\mathrm{Fe}$ and $\mathrm{S}$ (as $\mathrm{FeS}_{2}$ and $\left.\mathrm{FeS}_{\text {(mack) }}\right)$ to meet both $\mathrm{Fe}$ and $\mathrm{S}$ demands and that they may even prefer these forms over canonical forms (e.g., Fe(II) or $\mathrm{HS}^{-} /$cysteine).

\section{Comparing growth on $\mathrm{FeS}_{2}$ to growth under Fe or $\mathrm{S}$ limiting conditions}

To determine whether $M$. voltae can directly assimilate aqueous $\mathrm{HS}^{-}$and to verify that trace $\mathrm{Fe}$ or $\mathrm{S}$ in the cultivation medium was not sufficient to meet cellular demands, we compared the growth and activity of $M$. voltae cultures provided with only $\mathrm{FeS}_{2}$ to those provided with only $\mathrm{Fe}(\mathrm{II})$ or only $\mathrm{HS}^{-}$(SOM Fig. S6). When cells were provided with only $\mathrm{Fe}(\mathrm{II})$, there was no production of cells and $\mathrm{CH}_{4}$ production was minimal. However, production of cells and $\mathrm{CH}_{4}$ was observed in cultures provided with only $\mathrm{HS}^{-}$, albeit at $40 \%$ of the cell yield for $\mathrm{FeS}_{2}$-grown cells. These results indicate that trace $\mathrm{Fe}$ in the medium can partially fulfill biological demands in cultures provided with $\mathrm{HS}^{-}$but that trace S cannot, consistent with a higher demand for S than $\mathrm{Fe}$ in cells [22]. Our findings agree with the apparent ability of Class I and Class II methanogens to assimilate $\mathrm{HS}^{-}$during growth $[22,37]$. However, given that $\mathrm{HS}^{-}$ readily reacts with $\mathrm{Fe}(\mathrm{II})$ to form $\mathrm{FeS}_{(\mathrm{aq})}$ and $\mathrm{FeS}_{\text {(mack) }}$ and the fact that both $\mathrm{HS}^{-}$and $\mathrm{Fe}$ (II) tend to be provided in the growth medium of methanogens, it is likely that these and other Class I and II methanogens can assimilate $\mathrm{FeS}_{(\mathrm{aq})}$ or iron monosulfide precipitates and may supplement $\mathrm{S}$ demands by assimilating free $\mathrm{HS}^{-}$.

\section{Interactions between methanogens and $\mathrm{FeS}_{2}$}

The requirement for cells to associate with the surface of $\mathrm{FeS}_{2}$ for mineral-dependent growth was investigated using dialysis membrane experiments. M. voltae was grown with formate as the electron donor and with $\mathrm{FeS}_{2}$ free in solution or sequestered in dialysis membranes with $3.5 \mathrm{kDa}$ pore size to limit direct access to the mineral surface. Growth of $M$. voltae and the reduction of $\mathrm{FeS}_{2}$ was assessed by monitoring production of cells, $\mathrm{CH}_{4}$, and $\mathrm{HS}^{-}$(Fig. 3 and SOM Table S3). Cells, $\mathrm{CH}_{4}$, and $\mathrm{HS}^{-}$were produced when $\mathrm{FeS}_{2}$ was provided free in solution but not when $\mathrm{FeS}_{2}$ was sequestered in dialysis tubing with a $3.5 \mathrm{kDa}$ pore size (Fig. 3). Cells, $\mathrm{CH}_{4}$, and $\mathrm{HS}^{-}$were also not detected when $\mathrm{FeS}_{2}$ was sequestered in dialysis tubing with 25 , 50, or $100 \mathrm{kDa}$ pore sizes (data not shown), which would allow for the passage of small extracellular proteins or metabolites across the dialysis membrane that may be involved in $\mathrm{FeS}_{2}$ reduction or acquisition of reductive dissolution products. Collectively, these results indicate that cells require direct contact with $\mathrm{FeS}_{2}$ to catalyze its reduction and/or that cells require direct access to $\mathrm{FeS}_{2}$ to acquire $\mathrm{Fe}$ and $\mathrm{S}$ following the coupled reductive dissolution-precipitation reaction. Alternatively, these results could point to high molecular weight $(>100 \mathrm{kDa})$ extracellular proteins, metabolites, or other cellular assemblages (such as enzyme containing vesicles) as being involved in catalyzing $\mathrm{FeS}_{2}$ reduction or in acquiring mineral-associated $\mathrm{Fe}$ and $\mathrm{S}$. The involvement of vesicles in mineral sulfide oxidation has been demonstrated in the crenarchaeote Metallosphaera sedula, where they were shown to adhere to and promote the oxidation and solubilization of chalcopyrite $\left(\mathrm{CuFeS}_{2}\right)$ [38].

We therefore examined associations between $M$. voltae (and possible vesicles) and both synthetic and specimen forms of $\mathrm{FeS}_{2}$ using FE-SEM imaging (Fig. 4). We did not observe any vesicles, but this is potentially attributable to the $0.4 \mu \mathrm{m}$ pore size used for the EM grid which may not have allowed vesicles to be visualized. Rather, formategrown $M$. voltae cells provided with $\mathrm{FeS}_{2}$ were observed to 
be attached to the mineral during growth, perhaps mediated by extracellular appendages (Fig. 4a, b and SOM Figs. S7 and S8). Archaeal flagella, or archaella, are well characterized in $M$. voltae and other Archaea where they function in motility, attachment to surfaces, and in biofilm formation [39]. The apparent affinity for cells to attach to

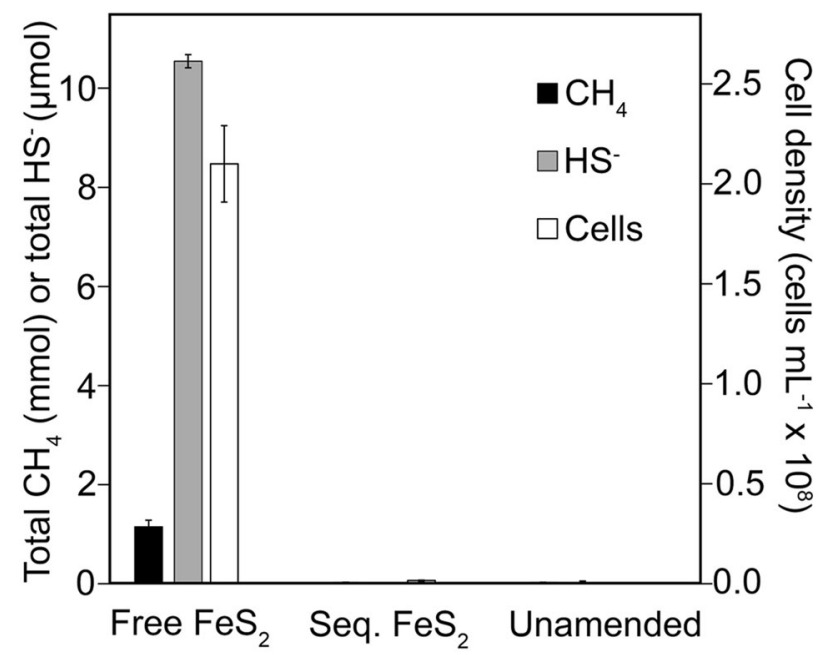

Fig. 3 Production of cells, methane, and sulfide in cultures of Methanococcus voltae provided with formate as the methanogenesis substrate and pyrite $\left(\mathrm{FeS}_{2}\right.$ ) in solution (free $\mathrm{FeS}_{2}$ ), $\mathrm{FeS}_{2}$ sequestered in dialysis membranes (seq. $\mathrm{FeS}_{2}$ ), or without $\mathrm{FeS}_{2}$ or other sources of $\mathbf{F e}$ or $\mathbf{S}$ (unamended). $\mathrm{FeS}_{2}$ was added to a final concentration of $2 \mathrm{mM} \mathrm{Fe}$. The cell density was determined after 5 days. Data shown are the mean values for each condition with error bars reflecting the standard deviation of three replicate biological reactors. $\mathrm{CH}_{4}$, methane; $\mathrm{HS}^{-}$, sulfide. See Supplementary Table 3 for data used to generate the plot. the mineral surfaces and form biofilms is further supported by observations that when cells are grown with $\mathrm{FeS}_{2}, \mathrm{CH}_{4}$ production (seen as bubble generation) and cellular biomass (biofilms) are co-localized with settled synthetic (Supplementary Video 1) or specimen (Supplementary Video 2) mineral grains. While one would expect bubble generation to occur more extensively on nucleation points under highly saturated conditions, this phenomenon is also observed early in growth when $\mathrm{CH}_{4}$ levels are low. These observations provide further evidence indicating that methanogens likely attach to mineral sources to meet $\mathrm{Fe}$ and $\mathrm{S}$ biosynthetic demands through bio-catalyzed reductive dissolution.

\section{Conclusions}

Data presented here reveal that representatives of both Class I and II methanogens, including strains from both freshwater (M. barkeri) and marine (M. voltae) environments, can catalyze the reductive dissolution of $\mathrm{FeS}_{2}$. This activity results in the liberation of $\mathrm{Fe}$ and $\mathrm{S}$, likely as precipitated secondary minerals such as $\mathrm{FeS}_{\text {(mack) }}$ and/or pyrrhotite, that are used to meet biosynthetic demands. These observations raise intriguing questions related to the mechanism(s) of biological $\mathrm{FeS}_{2}$ reduction, the mechanism(s) of iron monosulfide acquisition and assimilation, and intracellular processing and trafficking of iron monosulfide for [Fe-S] cluster, amino acid, cofactor, and vitamin biosynthesis. Further, these observations highlight the ability of methanogens to transform Earth abundant and inert iron sulfide minerals, such as $\mathrm{FeS}_{2}$, into co-factors for enzymes capable
Fig. 4 Field emission scanning electron micrographs (FESEM) of Methanococcus voltae cells grown with synthetic and specimen pyrite as the sole $\mathrm{Fe}$ and $S$ source. a Cells of $M$. voltae grown with synthetic pyrite $\left(\mathrm{FeS}_{2}\right)$ or b specimen $\mathrm{FeS}_{2}$. c Synthetic $\mathrm{FeS}_{2}$ or d specimen $\mathrm{FeS}_{2}$ in the absence of $M$. voltae. Samples were fixed with $2 \%$ glutaraldehyde before FE-SEM imaging on goldsputtered $0.2 \mu \mathrm{m}$ polycarbonate filters. Scale bar equals $0.5 \mu \mathrm{m}$ in $\mathbf{a}-\mathbf{c}$ and $1.0 \mu \mathrm{m}$ in $\mathbf{d}$.
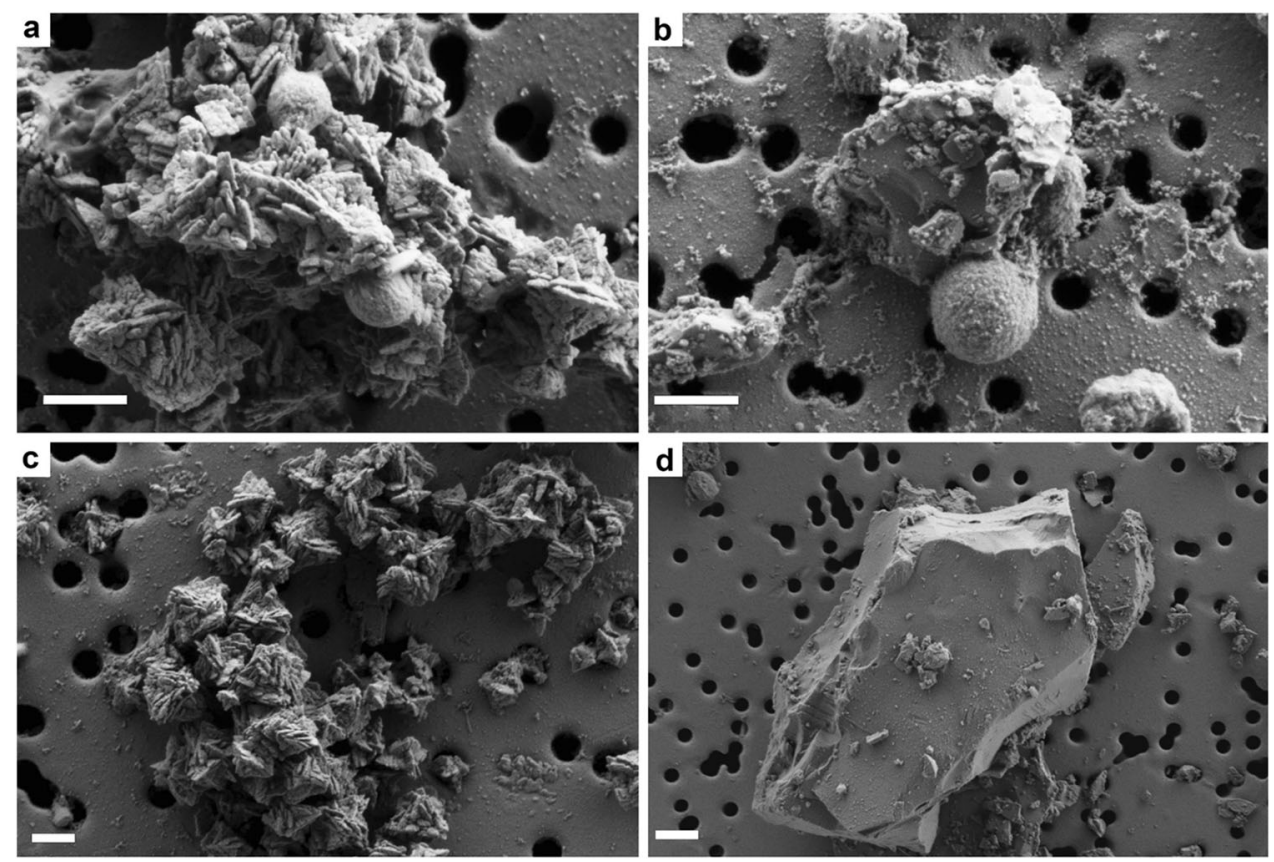
of interconverting substrates (e.g., $\mathrm{CO}_{2} / \mathrm{CH}_{4}$ and $\mathrm{H}^{+} / \mathrm{H}_{2}$ ) of ecological and biotechnological relevance. These enzymes include simple and complex [Fe-S] clusters associated with [NiFe]-hydrogenases, carbon monoxide dehydrogenases, and numerous other $\mathrm{Fe}-\mathrm{S}$ metalloproteins and co-factors synthesized by methanogens. The ability of anaerobic methanogens to acquire $\mathrm{Fe}$ and $\mathrm{S}$ from abundant mineral sources long considered to be non-bioavailable necessitates a re-evaluation of the $\mathrm{Fe}$ and $\mathrm{S}$ cycles in anoxic ecosystems of today and in the geological past.

Acknowledgements This work was supported by the Division of Chemical Sciences, Geosciences, and Biosciences, Office of Basic Energy Sciences of the U.S. Department of Energy through Grant DESC0020246 to ESB. DP was partially supported by a fellowship from the Montana Space Grant Consortium. We thank Dr. David Mogk and Elif Roehm for their assistance with electron microscopy at the Montana Nanotechnology Facility, a National Nanotechnology Infrastructure Center member supported by National Science Foundation Grant ECCS-1542210.

\section{Compliance with ethical standards}

Conflict of interest The authors declare no competing interests.

Publisher's note Springer Nature remains neutral with regard to jurisdictional claims in published maps and institutional affiliations.

Open Access This article is licensed under a Creative Commons Attribution 4.0 International License, which permits use, sharing, adaptation, distribution and reproduction in any medium or format, as long as you give appropriate credit to the original author(s) and the source, provide a link to the Creative Commons license, and indicate if changes were made. The images or other third party material in this article are included in the article's Creative Commons license, unless indicated otherwise in a credit line to the material. If material is not included in the article's Creative Commons license and your intended use is not permitted by statutory regulation or exceeds the permitted use, you will need to obtain permission directly from the copyright holder. To view a copy of this license, visit http://creativecommons. org/licenses/by/4.0/.

\section{References}

1. Berner RA. Sedimentary pyrite formation: an update. Geochim Cosmochim Acta. 1984;48:605-15.

2. Fike DA, Bradley AS, Rose CV. Rethinking the ancient sulfur cycle. Ann Rev Earth Planet Sci. 2015;43:593-622.

3. Canfield DE, Habicht KS, Thamdrup B. The archean sulfur cycle and the early history of atmospheric oxygen. Science. 2000;288:658-61.

4. Smith PE, Evensen NM, York D, Moorbath S. Oldest reliable terrestrial ${ }^{40} \mathrm{Ar}-{ }^{39} \mathrm{Ar}$ age from pyrite crystals at Isua west Greenland. Geophys Res Lett. 2005;32:L21318.

5. Lyons TW, Reinhard CT, Planavsky NJ. The rise of oxygen in Earth's early ocean and atmosphere. Nature 2014;506:307-15.

6. Canfield DE. The early history of atmospheric oxygen: homage to Robert M. Garrels. Annu Rev Earth Planet Sci. 2005;33:1-36.

7. Langmuir D. Aqueous environmental geochemistry. Vol. 8. Upper Saddle River, New Jersey: Prentice Hall; 1997.
8. Farquhar J, Bao H, Thiemens M. Atmospheric influence of Earth's earliest sulfur cycle. Science. 2000;289:756-8.

9. Anbar AD, Duan Y, Lyons TW, Arnold GL, Kendall B, Creaser RA, et al. A whiff of oxygen before the great oxidation event? Science. 2007;317:1903-6.

10. Truche L, Berger G, Destrigneville C, Guillaume D, Giffaut E. Kinetics of pyrite to pyrrhotite reduction by hydrogen in calcite buffered solutions between 90 and $180^{\circ} \mathrm{C}$ : implications for nuclear waste disposal. Geochim Cosmochim Acta. 2010;74:2894-914.

11. Hall AJ. Pyrite-pyrrhotine redox reactions in nature. Miner Mag. 1986;50:223-9.

12. Thiel J, Byrne JM, Kappler A, Schink B, Pester M. Pyrite formation from $\mathrm{FeS}$ and $\mathrm{H}_{2} \mathrm{~S}$ is mediated through microbial redox activity. Proc Nat Acad Sci USA. 2019;116:6897-902.

13. Rickard D. Kinetics of pyrite formation by the $\mathrm{H}_{2} \mathrm{~S}$ oxidation of iron (II) monosulfide in aqueous solutions between 25 and $125^{\circ} \mathrm{C}$ : the rate equation. Geochim Cosmochim Acta. 1997;61:115-34.

14. Schoonen MAA. Mechanisms of sedimentary pyrite formation. In: Sulfur biogeochemistry_past and present. Amend JP, Edwards KJ, Lyons TW, editors. Geological Society of America; 2004. p. 379.

15. Beinert H, Holm RH, Munck E. Iron-sulfur clusters: nature's modular, multipurpose structures. Science. 1997;277:653-9.

16. Johnson DC, Dean DR, Smith AD, Johnson MK. Structure, function, and formation of biological iron-sulfur clusters. Annu Rev Biochem. 2005;74:247-81.

17. Imlay JA. Iron-sulphur clusters and the problem with oxygen. Mol Microbiol. 2006;59:1073-82.

18. Ayala-Castro C, Saini A, Outten FW. Fe-S cluster assembly pathways in bacteria. Microbiol Mol Biol Rev. 2008;72:110-25.

19. Russell MJ, Martin W. The rocky roots of the acetyl-CoA pathway. Trends Biochem Sci. 2004;29:358-63.

20. Weiss MC, Sousa FL, Mrnjavac N, Neukirchen S, Roettger M, Nelson-Sathi S, et al. The physiology and habitat of the last universal common ancestor. Nat Microbiol. 2016;1:16116.

21. Ueno Y, Yamada K, Yoshida N, Maruyama S, Isozaki Y. Evidence from fluid inclusions for microbial methanogenesis in the early Archaean era. Nature. 2006;440:516.

22. Liu Y, Sieprawska-Lupa M, Whitman WB, White RH. Cysteine is not the sulfur source for iron-sulfur cluster and methionine biosynthesis in the methanogenic archaeon Methanococcus maripaludis. J Biol Chem. 2010;285:31923-9.

23. Major TA, Burd H, Whitman WB. Abundance of $4 \mathrm{Fe}-4 \mathrm{~S}$ motifs in the genomes of methanogens and other prokaryotes. FEMS Microbiol Lett. 2004;239:117-23.

24. Whitman WB, Shieh J, Sohn S, Caras DS, Premachandran U. Isolation and characterization of 22 mesophilic methanococci. Syst Appl Microbiol. 1986;7:235-40.

25. Koster IW, Rinzema A, de Vegt AL, Lettinga G. Sulfide inhibition of the methanogenic activity of granular sludge at various $\mathrm{pH}$ levels. Water Res. 1986;20:1561-7.

26. Paulo LM, Stams AJM, Sousa DZ. Methanogens, sulphate and heavy metals: a complex system. Rev Environ Sci Bio. 2015;14:537-53.

27. Luther GW, Rickard DT. Metal sulfide cluster complexes and their biogeochemical importance in the environment. J Nanopart Res. 2005;7:389-407.

28. Rickard D. The solubility of FeS. Geochim Cosmochim Acta. 2006;70:5779-89.

29. Rickard D, Luther GW. Chemistry of iron sulfides. Chem Rev. 2007;107:514-62.

30. Schippers A, Jørgensen BB. Biogeochemistry of pyrite and iron sulfide oxidation in marine sediments. Geochim Cosmochim Acta. 2002;66:85-92. 
31. Bryant MP, Boone DR. Emended description of strain $\mathrm{MS}^{\mathrm{T}}$ (DSM $800^{\mathrm{T}}$ ), the type strain of Methanosarcina barkeri. Int J Syst Evol. 1987;37:169-70.

32. Berner RA. The synthesis of framboidal pyrite. Econ Geol. 1969;64:383-84.

33. Whitman WB, Ankwanda E, Wolfe RS. Nutrition and carbon metabolism of Methanococcus voltae. J Bacteriol. 1982;149:852-63.

34. Fogo JK, Popowsky M. Spectrophotometric determination of hydrogen sulfide. Anal Chem. 1949;21:732-4.

35. Alistair RL, Katharine ERE, David JV. Transformation of synthetic mackinawite to hexagonal pyrrhotite: a kinetic study. Am Miner. 1995;80:960-7.
36. Benning LG, Wilkin RT, Barnes HL. Reaction pathways in the $\mathrm{Fe}-\mathrm{S}$ system below $100{ }^{\circ} \mathrm{C}$. Chem Geol. 2000;167:25-51.

37. Rauch BJ, Perona JJ. Efficient sulfide assimilation in Methanosarcina acetivorans is mediated by the MA1715 protein. J Bacteriol. 2016;198:1974.

38. Johnson TB, Mach C, Grove R, Kelly R, Van Cott K, Blum P. Secretion and fusion of biogeochemically active archaeal membrane vesicles. Geobiology. 2018;16: 659-73.

39. Jarrell KF, Ding Y, Nair DB, Siu S. Surface appendages of archaea: structure, function, genetics and assembly. Life. 2013;3: 86-117. 